Article

\title{
Integrated Impact Assessment for Sustainable Hydropower Planning in the Vjosa Catchment (Greece, Albania)
}

\author{
Rebecca Peters ${ }^{1, *}$, Jürgen Berlekamp ${ }^{2}\left(\mathbb{D}\right.$, Ana Lucía ${ }^{1}$, Vittoria Stefani ${ }^{3}{ }^{(D}$, Klement Tockner ${ }^{4,5}$ \\ and Christiane Zarfl ${ }^{1}$ (D) \\ 1 Center for Applied Geoscience, Eberhard Karls University of Tübingen, 72076 Tübingen, Germany; \\ ana.lucia@ifg.uni-tuebingen.de (A.L.); christiane.zarfl@uni-tuebingen.de (C.Z.) \\ 2 Institute of Environmental Systems Research, University of Osnabrück, 49076 Osnabrück, Germany; \\ juergen.berlekamp@uni-osnabrueck.de \\ 3 Department of Civil, Environmental and Mechanical Engineering, University of Trento, 38123 Trento, Italy; \\ vittoria.stefani1994@gmail.com \\ 4 Senckenberg Gesellschaft für Naturforschung, 60325 Frankfurt a. M., Germany; \\ klement.tockner@senckenberg.de \\ 5 Faculty of Biological Sciences, Goethe-University, 60323 Frankfurt a. M., Germany \\ * Correspondence: rebecca.peters@uni-tuebingen.de; Tel.: +49-(0)7071-29-73481
}

Citation: Peters, R.; Berlekamp, J.; Lucía, A.; Stefani, V.; Tockner, K.;

Zarfl, C. Integrated Impact

Assessment for Sustainable Hydropower Planning in the Vjosa Catchment (Greece, Albania).

Sustainability 2021, 13, 1514. https://

doi.org/10.3390/su13031514

Academic Editor:

Enrique Rosales-Asensio

Received: 22 December 2020

Accepted: 26 January 2021

Published: 1 February 2021

Publisher's Note: MDPI stays neutral with regard to jurisdictional claims in published maps and institutional affiliations.

Copyright: (c) 2021 by the authors. Licensee MDPI, Basel, Switzerland. This article is an open access article distributed under the terms and conditions of the Creative Commons Attribution (CC BY) license (https:// creativecommons.org/licenses/by/ $4.0 /)$.

\begin{abstract}
Mitigating climate change, while human population and economy are growing globally, requires a bold shift to renewable energy sources. Among renewables, hydropower is currently the most economic and efficient technique. However, due to a lack of impact assessments at the catchment scale in the planning process, the construction of hydropower plants (HPP) may have unexpected ecological, socioeconomic, and political ramifications in the short and in the long term. The Vjosa River, draining parts of Northern Greece and Albania, is one of the few predominantly free-flowing rivers left in Europe; at the same time its catchment is identified an important resource for future hydropower development. While current hydropower plants are located along tributaries, planned HPP would highly impact the free-flowing main stem. Taking the Vjosa catchment as a case study, the aim of this study was to develop a transferable impact assessment that ranks potential hydropower sites according to their projected impacts on a catchment scale. Therefore, we integrated established ecological, social, and economic indicators for all HPP planned in the river catchment, while considering their capacity, and developed a ranking method based on impact categories. For the Vjosa catchment, ten hydropower sites were ranked as very harmful to the environment as well as to society. A sensitivity analysis revealed that this ranking is dependent upon the selection of indicators. Small HPP showed higher cumulative impacts than large HPP, when normalized to capacity. This study empowers decision-makers to compare both the ranked impacts and the generated energy of planned dam projects at the catchment scale.
\end{abstract}

Keywords: dams; sediment entrapment; river fragmentation; human resettlement; river management; small reservoirs; renewable energies; sustainable development; biodiversity

\section{Introduction}

Humankind faces competing tasks in meeting increasing energy demands while mitigating global warming. During the past decades, the dominance of fossil fuels has generated stress onto Earth's natural systems [1,2]. Hence, mitigating global warming is part of the Agenda 2030 within the Sustainable Development Goals 7 "Affordable Energy" and 13 "Climate Action".

Investments in renewables and particularly in hydropower are important steps towards a sustainable future [3]. According to the International Energy Agency (IEA) report (2018), the renewable sectors hydropower, solar energy, and wind power need to expand in order to meet long-term climate goals as well as increasing energy demands [1]. 
Globally, hydropower accounts for around $60 \%$ of the electricity supply generated from renewables [1]. As hydropower is still the most efficient renewable energy source, it is an irreplaceable part of the current renewable energy mix [4]. Concurrently, we are facing a new global boom in hydropower dam development; at least 3700 dams [ $\geq 1$ megawatt (MW)] are either planned or under construction worldwide [5].

At present, $37 \%$ of rivers longer than $1000 \mathrm{~km}$ remain free-flowing, and this proportion will further decrease in the near future [6]. Hydropower is a renewable electricity source, but not per se climate-neutral; furthermore, it has multiple ecological, social, economic, and political ramifications (Figure 1).

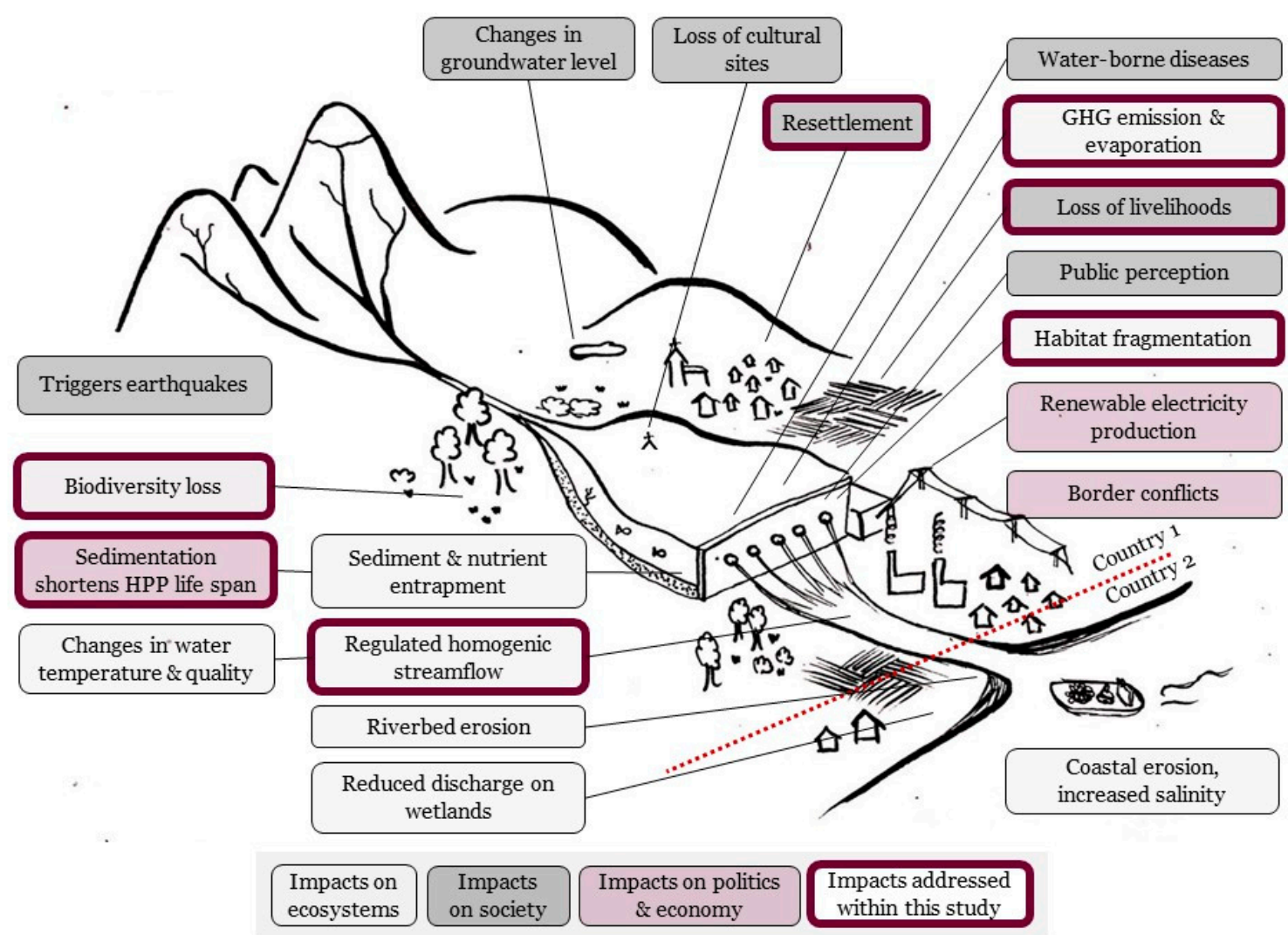

Figure 1. Ecological, social, political, and economic impacts induced by hydropower construction. Bold-framed impacts are addressed in the present study. Used abbreviation: Greenhouse gas (GHG).

Dam construction and reservoir formation impact the functioning of freshwater ecosystems: Water and sediment connectivity are reduced, fluvial geomorphology altered $[7,8]$, biogeochemical processes truncated [9], and biodiversity threatened due to habitat fragmentation, over-exploitation, pollution, species invasion, and inhibited animal migration [10-12]. Furthermore, dam-induced resettlement provokes social conflicts with resettled people remaining uninformed and not sufficiently compensated for the loss of their livelihoods [13-16]. Dam construction affects public health too [17]; and it may even trigger earthquakes [18]. Moreover, cost overruns are common due to wrong site selection and inadequate planning, which again provokes major economic and political impacts [19]. Hydropower facilities change existing landscapes and affect public perception which influences national and international politics [20]. Finally, as about $60 \%$ of large rivers cross country borders, international conflicts may emerge [21,22].

The ecological, social, economic, and political ramifications of HPP are diverse and vary with time and space. For example, the future development of hydropower and its related impacts depend on global warming because changes in temperature and precipitation influence the production, consumption, and transmission of electricity [23]. Effects are additive or synergistic on regional to global scales [24,25]. 
So far, global research has focused on the unintended consequences of large dams, while information on the impacts of small dams remains scarce [25-31]. However, the capacity of HPP must be considered when assessing the multifaceted impacts of hydropower development in relation to its benefits like renewable electricity production [32]. For example, studies in China, Norway, and Spain demonstrated that the cumulative effects of small HPP (SHP) exceed the impact of single large HPP (LHP), when normalized to capacity [33-35]. Nevertheless, SHP development gains speed globally because it is promoted as a global warming mitigation strategy. Therefore, national regulations favor SHP even though their ecological, social, and economic impacts are either underestimated or even neglected [25]. In the Balkan region, Albania is a forerunner in SHP development, with an estimated 111 power plants ( $<10 \mathrm{MW}$ each) constructed since 2009 [36]. Susaj et al. (2018) stated that most small HPP were approved by "relevant authorities [ ... ] without or fictitious EIA" (Environmental Impact Assessments), which again restricts sustainable development [37].

The Hydropower Sustainability Assessment Protocol (HSAP) is a tool that aims to address the impacts of an HPP during its project cycle (i.e., planning, preparation, implementation, and operation). The HSAP has been developed and reviewed by different stakeholders from the hydropower sector, environmental and social NGOs, development banks, and governments. It was published first in 2010, and re-edited in 2018 [38]. By including environmental, social, technical, and economic/financial perspectives, the voluntary and non-binding auditing tool can help score the sustainability of HPP projects. However, the tool is lacking specific scientific guidance and standardized methods on assessing specific impacts. Additionally, the project-based assessment tool does not compare different HPP sites, nor size (capacity) options, or cumulative impacts [39,40]. Nevertheless, the HSAP is broadening the focus by including ecological, social, and economic impacts, a prerequisite for an adequate and comprehensive impact assessment of planned HPP on both regional and global scales. In comparison to the existing Eco-Masterplan for Balkan Rivers, which only covers environmental impacts, the HSAP applies a broader, integrative assessment approach [41].

The present study aims to develop and test an integrated impact assessment approach that supports decision makers in HPP construction on a catchment scale applying ecological, social, and political indicators. This approach helps to balance the pros and cons with respect to the location and the capacity of planned HPP. Taking the transboundary Vjosa catchment (Greece, Albania) as a case study, (1) impacts were assessed and integrated for potential dam locations and, based on the outcome, a ranking of all planned HPP was derived, (2) the effects of the selection of indicators on the total ranking were tested, and (3) normalized effects of several SHP were compared to the predicted effects of few LHP. This integrated impact assessment is considered a transferable approach that can be applied well beyond the Vjosa catchment. In addition, it is not restricted to specific placements or size characteristics of a catchment. Indicators for additional impacts can be added and integrated to address local catchment characteristics, which again allows a broad and context-specific application of the present approach.

\section{Materials and Methods}

\subsection{Study Site: Vjosa Catchment}

The Vjosa River (main stem of Vjosa catchment) is among of the very few free-flowing rivers remaining in Europe. The 272-km-long river starts in the Pindus Mountains (Greece), crosses Southern Albania, and enters the Adriatic Sea near Vlora [42]. The high number of intact tributaries makes the Vjosa a unique catchment system [41]. In Greece, the 80-km-long river section is called Aoos; however, for simplicity reasons, we use the term "Vjosa" for the entire river system. The catchment covers an area of $6704 \mathrm{~km}^{2}$ (Albania: $65 \%$; Figure 2), and the average discharge at the mouth amounts to $204 \mathrm{~m}^{3} / \mathrm{s}$. The Vjosa exhibits a characteristic Mediterranean flow regime, with the highest average discharge in winter (February) and the lowest average discharge in summer (August/September). 
It is classified as a laterally active gravel-bed river that exhibits near-natural flow and sediment regimes [42,43]. The Vjosa is of particular importance for the conservation of the European fish fauna due to a high share of endemic species [44]. Schiemer et al. (2020) stated that in the case of the planned dam constructions, its unique biodiversity will most likely disappear $[42,45]$.

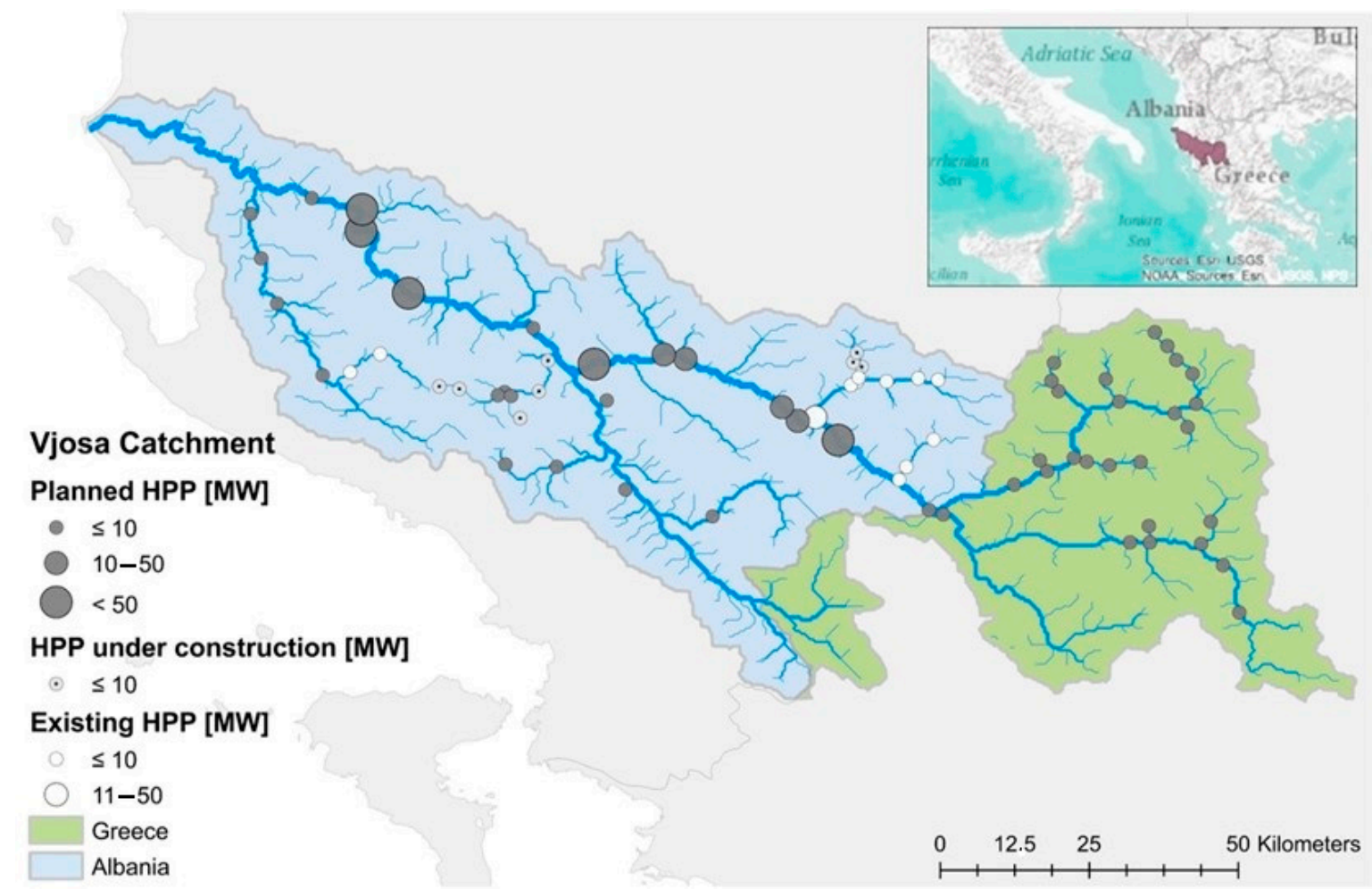

Figure 2. Vjosa catchment in Greece (green) and Albania (blue), and the location of hydropower plants (HPP; existing, under construction, planned; size in megawatt (MW)) along the main stem and its major tributaries.

The Vjosa River system provides major social and economic benefits for nearby residents: It provides irrigation water for crop production and livestock farming as well as water for fisheries [46]. Currently, twelve HPP are in operation and eight HPP are under construction along the tributaries of the Vjosa catchment in Albania (Figure 2); an additional $51 \mathrm{HPP}$ are in the planning phase that would affect the free-flowing main stem of the Vjosa as well as the upstream catchment located in Greece. In contrast, national and international non-governmental organizations are promoting the creation of a "wild river" national park [47].

\subsection{Methodological Approach}

\subsubsection{Indicator Selection}

Using the HSAP as a foundation, the present work expands the impact assessment by selecting several ecological, social, and economic indicators (see Figure 1). All planned HPP on a catchment scale were included in order to permit comparisons among different projects [38]. The methods applied are objective and reproducible. Indicators were selected based on the following conditions: First, the set of selected indicators represented measurable ecological, social, and economic impacts to underpin the idea of assessing dam locations in the frame of sustainability. Second, comprehensive and high-resolution spatial data were available via open access platforms. While the indicators River Regulation, River Fragmentation, and Sediment Entrapment measured effects that could be traced back directly to the construction of an HPP (including a dam wall), the indicators Megafauna, Protected Area, Land Use Change, Resettlement, and Potential Evaporation 
depicted indirect effects that were caused by the flooding of an area (projected reservoir areas).

2.2.2. Datasets and Calculation of Impacts (Impact Assessment) for Every Selected Indicator

The dataset of existing and planned HPP in the Vjosa catchment was obtained by combining available data from the Global Reservoir and Dam Database (GRanD; [48]), the Global Geo-referenced Database of Dams (GOOD ${ }^{2}$; [49]), and the Future Hydropower Reservoirs and Dams Database (FHReD; [5]). It was updated with additional information from the Eco-Masterplan of Balkan Rivers and additional Riverwatch Data [41,46,50]. Only HPP with a dam wall and the formation of a reservoir upstream of the dam were included. For all HPP, the dataset included information on location of existing and projected reservoir areas (Appendix A). According to Global Dam Watch, only HPP with a capacity exceeding $1 \mathrm{MW}$ were considered. A list of all HPP, their locations, and characteristics can be found in Appendix A.

Calculation of the indicators River Regulation, River Fragmentation, and Sediment Entrapment included information on existing and planned hydropower plants. Impact calculations of all other single indicators were based on projected reservoir areas $\left[\mathrm{km}^{2}\right]$ and considered planned HPP only. All calculations were carried out and their results visualized with ArcMap 10.7 [51].

For River Regulation and Fragmentation, the River Regulation Index (RRI) and the River Fragmentation Index (RFI) were calculated, including the current degree of regulation and fragmentation caused by existing HPP, applying the methodology developed by Grill et al. [52]. The basis for these calculations formed the HydroSHEDS database [53] and HydroBASINS dataset (Level 4, Level 10) [54]. Additionally, WaterGAP discharge data were used [55]. The years until the reservoir area would be fully filled with eroded sediment were obtained by Stefani [50], considering the entire system including the existing and the projected reservoirs. She used a revised version of the Universal Soil Loss Equation (USLE), an empirical model to predict the annual average soil erosion from runoff using information on soil properties, rainfall, topography, and land use [56,57], combined with a Connectivity Index to estimate how much of the eroded soil would arrive to the fluvial network and the Cascade Model to quantify the amount of sediment transported along the fluvial network towards the reservoir areas $[6,58]$. We calculated projected reservoir areas and volumes as follows: First, dam capacities and site-specific river discharges from the WaterGAP model [59] were used to estimate each reservoirs' maximum water level. Second, reservoir areas and volumes were derived by GIS operations from the DEM provided by the HydroSHEDS database $[53,60]$. The technical procedure is described in detail by Stefani [50].

To estimate the number of megafauna freshwater species $(\geq 30 \mathrm{~kg})$ including reptiles, amphibians, and mammals, we overlapped freshwater megafauna data with projected reservoir areas [11,61]. Following a similar procedure, projected reservoir areas were intersected with protected areas using a polygon layer of the World Database on Protected Areas [62]. For the indicator Land Use Change, we used Land Cover Maps from 2015 (Land Cover Maps v2.0.7) provided by the European Space Agency's Climate Change Initiative with a resolution of $300 \mathrm{~m} \times 300 \mathrm{~m}$ [63]. The raster layer was transformed into a polygon layer and clipped to each projected reservoir area separately. We differentiated between land use changes in vegetation cover (forests, shrubland, and grassland) and agricultural land, and calculated land use changes separately. This distinction was made because land use change was classified as an economic and vegetation cover as an ecological indicator.

In order to estimate the number of people that must be resettled, we overlapped projected reservoir areas with a population raster dataset obtained by the WorldPop Project with a resolution of 3 arc seconds [64]. The potential evaporation values [mm/year] were obtained by the FAO GeoNetwork database with a resolution of 10 arc minutes [65]. Evaporation values of the raster feature were bound to reservoir points, and potential 
evaporation $\left[\mathrm{m}^{3} /\right.$ year] was calculated by multiplying each reservoir area $\left[\mathrm{m}^{2}\right]$ with its respective evaporation value $[\mathrm{mm} /$ year]

More details on all calculation procedures including mathematical formulas are provided in the Supplementary Materials (S1).

The correlation between independent indicators and projected reservoir areas was tested with R using the rank correlation coefficient Spearman's rho.

\subsubsection{Ranking of Planned HPP Considering All Indicators and Indicator Compositions}

The impacts of planned HPP in the Vjosa catchment were assessed. First, indicators of ecological, social, and economic relevance were analysed separately. Therefore, planned HPP were ranked for one indicator at a time according to their calculated impact. Following the ranking of each single indicator, every HPP was given the value of the respective quartile they belonged to, from 1 representing the lowest impact to 4 representing the highest impact. Second, quartile values were summed for each planned HPP. Every planned HPP was ranked according to their overall impact (sum of quartiles). Because impacts of large environmental projects occur in various sectors on different scales and across time, it can be crucial to test if a change of a certain input parameter or an input parameter composition changes the outcome [66]. In order to test this sensitivity of the model to the composition of the indicators, analyses were re-run in a "leave-one-out" fashion (one indicator was excluded at a time, local sensitivity approach $[66,67]$ ), and then again through excluding several indicators by creating different scenarios. After the exclusion of one or more indicators at a time, a ranking was created and compared with the original ranking. Results of the impact assessment considering single indicators, all indicators and indicator compositions were compared among each other (Figure 3 ) and visualized with ArcMap [51].

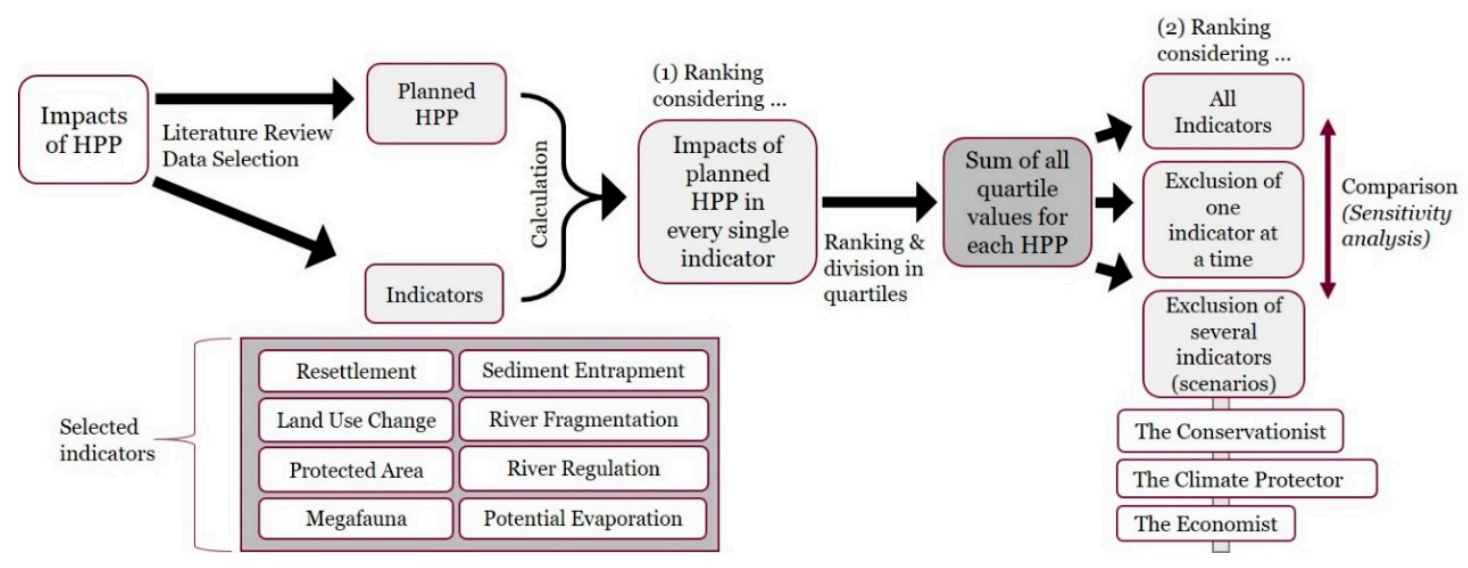

Figure 3. Methodological approach (Sections 2.2.1-2.2.3): Impact Assessment of planned HPP and ranking for every single indicator (1) and for different indicator compositions (2).

Created potential scenarios were based on an approach used by Middendorf et al. [67]. The "Conservationist" consisted of the indicators Protected Area, Land Use ChangeVegetation Cover, River Regulation, and River Fragmentation. The "Economist" combined Resettlement, Land Use Change-Agriculture, and Sediment Entrapment, and the "Climate Protector" included Potential Evaporation, Land Use Change-Vegetation Cover, Sediment Entrapment, and Protected Area. The indicator Sediment Entrapment was included as a proxy for HPP life span within the "Climate Protector" scenario. Other compositions are possible and reasonable. The created scenarios are examples that intended to show that rankings at catchment level generally depend on the selection of indicators. 


\subsubsection{Comparison of Small and Large Hydropower Plants}

To compare potential impacts of large hydropower plants (LHP, $>10 \mathrm{MW}$ ) with the potential impacts of small ones (SHP, 1-10 MW) in the Vjosa catchment area, cumulative impacts for each indicator were calculated and normalized to the installed capacity for scenarios with SHP only and with LHP only. For each indicator, a nonparametric MannWhitney $U$ Test for independent samples was conducted to test for significant differences between LHP and SHP. Analyses were carried out with R [68].

\section{Results}

\subsection{Site Selection-Impact Assessment and Ranking of Planned Hydropower Plants}

\subsubsection{Impact Assessment and Ranking of Planned HPP for Selected Indicators}

The degree of regulation (River Regulation Index: RRI) of the Vjosa sub-catchments would range between $3 \%$ and $382 \%$, if all planned HPP were constructed (calculation includes effects of existing HPP). The RRI is a discharge-weighted index for the change in the natural flow regime by the water storage of reservoirs in the catchment. The degree of fragmentation (River Fragmentation Index: RFI) of sub-catchments ranged from 16\% to $70 \%$. RRI and RFI values peaked in the upper Vjosa catchment (Figures S7, S8). Along the lower main river course, free-flowing tributaries led to a decrease of the degree of regulation and fragmentation (Figures S7, S8, and Figure 2).

The area flooded by all HPP combined (i.e., total reservoir area) was estimated to be $246 \mathrm{~km}^{2} ; 178 \mathrm{~km}^{2}$ cover agricultural land, $54 \mathrm{~km}^{2}$ other vegetated areas (i.e., forests, shrubland, grassland), and the remaining area includes bare soil and urban cover (Figure S8). Consequently, a total of 33,365 people, actually living in potentially flooded areas, would need to be resettled (Figure S10). In the Greek catchment, planned HPP would inundate $28 \mathrm{~km}^{2}$ of protected area (Figure S11).

Planned HPP would affect two megafauna freshwater species (Cyprinus carpio, Salmo trutta), both common within each sub-catchment. Thus, the megafauna indicator was not further included in the ranking assessment, because it did not affect the overall ranking of planned HPP.

If all planned HPP were realized, it would take between 16 and 330 thousand years until projected reservoirs would be filled with sediment (Figure S12). Moreover, projected reservoirs would cause $4,534,351 \mathrm{~m}^{3}$ /year of potential evaporation; a five-fold increase compared to present potential evaporation caused by existing lakes and reservoirs (Figure S13).

Impacts of existing and planned HPP and the rankings of planned HPP per indicator are listed in the Supporting Materials (Tables S2 and S3, Figures S7-S13).

\subsubsection{Impact Assessment and Ranking of Planned HPP Considering all Indicators}

Based on the eight indicators selected, the aggregated impact value could potentially range from eight (i.e., all indicators reflect lowest impact values) to 32 (i.e., all indicators reflect highest impact values). For each planned HPP, the calculated total value (all indicators combined) varied between 13 and 27 (mean: $19.5 \pm 3.4$, Figure 4).

All planned large HPP (LHP, $>10 \mathrm{MW}$ ) were assessed to cause high impact (third and fourth quartile, Figure 4). Twenty-six small HPP (SHP; $\leq 10 \mathrm{MW}$ ) were assessed to cause low impact (first and second quartile) on their surroundings and the river system (Figure 4), while 16 SHP were assessed to cause high impact (third and fourth quartile), suggesting that capacity size is not a good proxy predictor for high impact HPP. A total of 26 SHP and none of the LHP were assessed to cause low impact (first and second quartile).

Not all planned and top-ranked HPP shared the same outcome for the single indicator impact assessment: One Albanian HPP (Përmet; $25 \mathrm{MW}$ ) was not in the top quartile of any indicator, but consistently ranked with high values (7 indicators upper-middle and 1 time lower-middle quartile). In contrast, other HPP such as NN10 (10 MW, Greece) and Kaludhi (75 MW, Albania) were within the top quartile in 5 out of 8 indicators and represented the highest ranked HPP of the overall impact assessment (Appendix A, Table S3). 


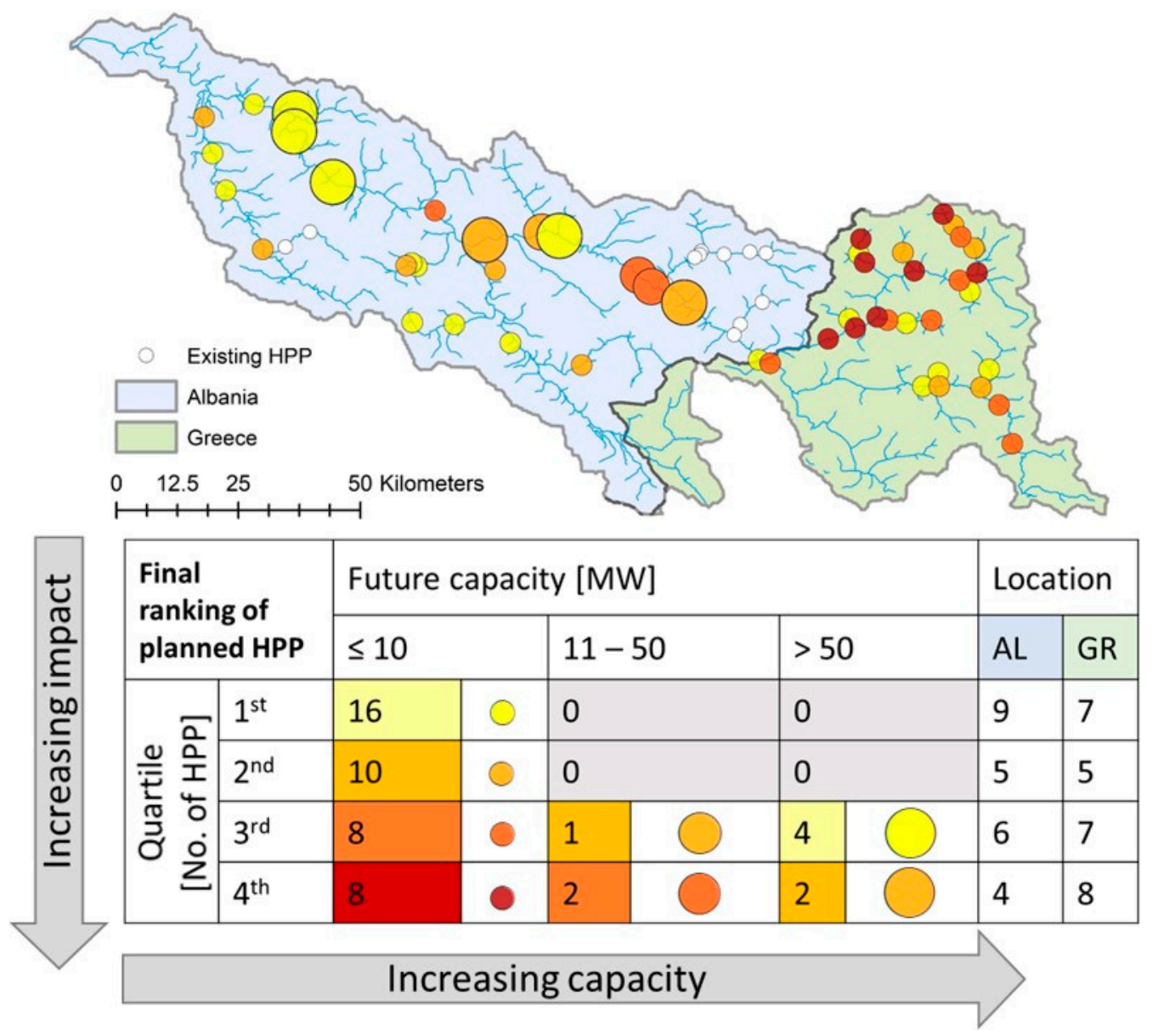

Figure 4. Results of the impact assessment including all indicators: Circles indicate existing (white color) or planned (other colors) hydropower plants (HPP). For planned HPP, circle size increases with capacity (3 categories: $\leq 10,11-50$, $>50$ megawatt (MW)). Color intensity (from light yellow to dark red) increases with impact and decreases with capacity. The table shows the total number of HPP in each category. All planned HPP are assigned to a quartile according to their total impact rank (i.e., sum of the indictors in quartiles). The magnitude of impact is increasing from the lowest (first), lower-middle (second), upper-middle (third), to the top (fourth) quartile. The location columns indicate how many planned HPP within each quartile are located on Albanian (AL) or on Greek (GR) territory.

Overall ranking of each planned HPP (i.e., sum of the indicators in quartiles) is listed in the Supplementary Materials (Table S3). Spearman's correlation coefficients did not yield strong or very strong relationships among individual indicators ( $\mathrm{rs}>0.6$, $\mathrm{rs}<-0.6$ ), with few exceptions (Table S5).

\subsubsection{Impact Assessment and Ranking Considering Different Indicator Compositions}

Three scenarios were created to assess the impact of different indicator compositions on the total ranking. The scenario "Conservationist" included the indicators Protected Area, Land Use Change-Vegetation Cover, River Regulation, and River Fragmentation. Applying this scenario, HPP planned in the upper catchment ranked very high (i.e., located in top quartile, Figure 5). The scenario "Economist" covered Resettlement, Land Use Change-Agriculture, and Sediment Entrapment. It exhibited an opposing trend (Figure 5), with HPP planned in the downstream area exhibiting the highest impact values (i.e., located in the top quartile). The "Climate Protector" scenario included Potential Evaporation, Land Use Change-Vegetation Cover, Sediment Entrapment, and Protected Area. All HPP ranked high in the scenario "Climate Protector" (fourth quartile, five in total) were also within the top quartile (fourth quartile) of one or both other scenarios (Figure 5, turquoise symbols and asterisk). 


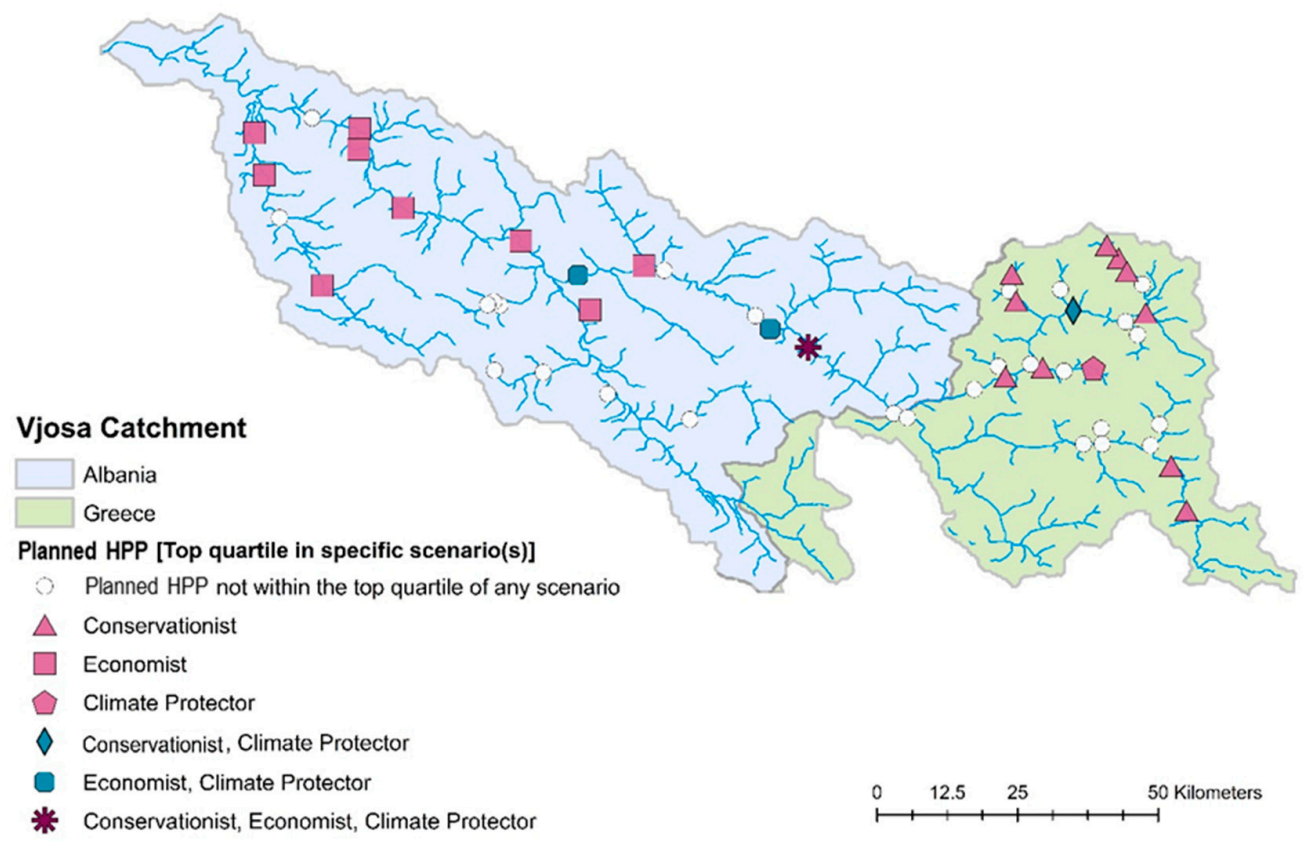

Figure 5. Results of the impact assessment by applying three different scenarios (see text): Symbols indicate existing (white circles) or planned (coloured symbols) hydropower plants (HPP). Planned HPP located in the top quartile of one or more scenarios are of different shape; different colours indicate the number of assignments to scenarios (1 (pink), 2 (turquoise), 3 (purple)).

The HPP Kaludhi (75 MW, Greece) was assigned to the top quartile in all three scenarios (Figure 5, asterisk), which was consistent with the results from the overall impact assessment (Figure 4, Appendix A, Table S3).

\subsection{Capacity Size Selection-Comparison of Small and Large Hyropower Plants}

In total, 42 SHP (1-10 MW) and 9 LHP (>10 MW) are planned in the Vjosa catchment area. The capacity of the LHP combined would be twice as high as the capacity of all SHP. The reservoir area, however, would be 1.5 times of the area flooded by SHP (Figure 6a). As expected, there was a positive relationship between planned capacity and projected reservoir size (Figure $6 \mathrm{~b}$ ), although reservoir size of some SHP would exceed the area of mid-sized LHP (25 to $75 \mathrm{MW}$ ).

(a)

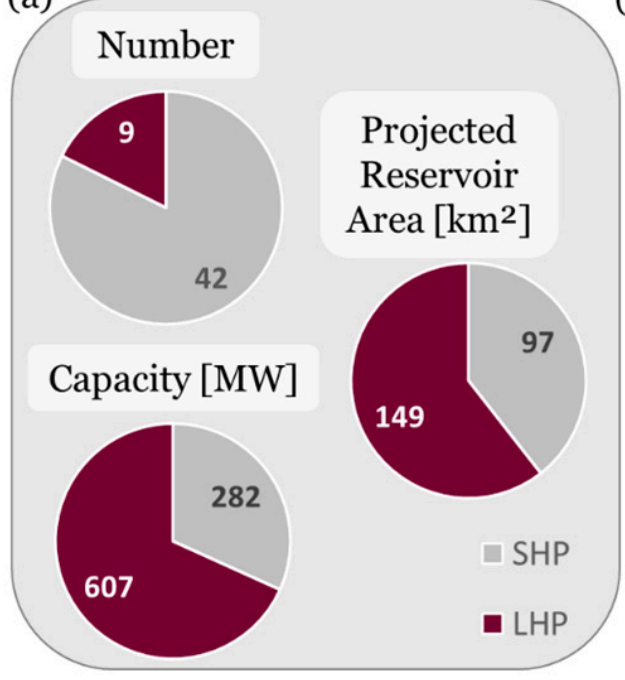

(b)

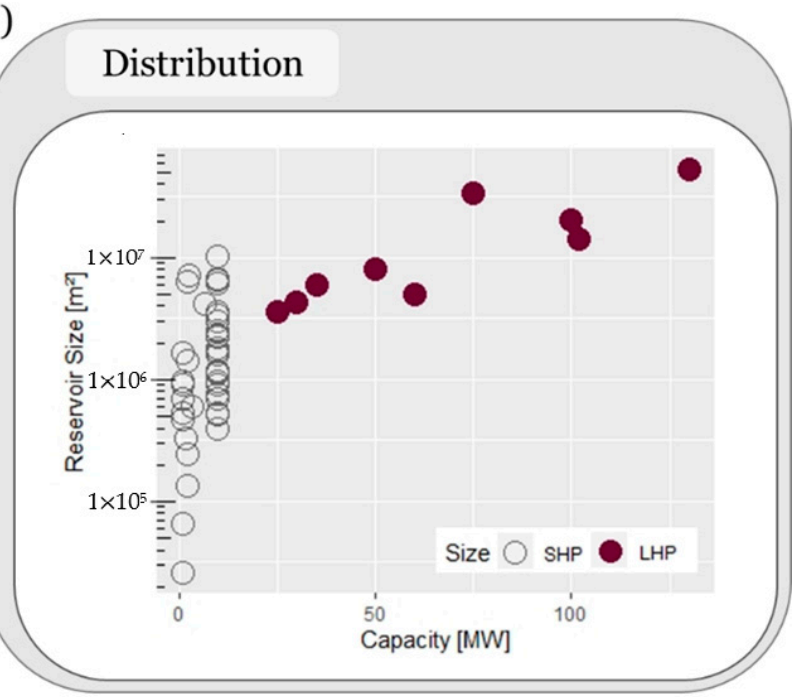

Figure 6. Characteristics and distribution of all small (SHP, gray, $n=42)$ and large (LHP, purple, $n=9$ ) hydropower plants in the Vjosa catchment: (a) Total number, capacity [megawatt (MW)], and projected reservoir area $\left[\mathrm{km}^{2}\right]$; (b) reservoir size (surface area, $\mathrm{m}^{2}$ ) as a function of capacity. 
Cumulated impacts, normalized to capacity, differed significantly between LHP and SHP in the categories Land Use Change-Vegetation Cover, Sediment Entrapment, River Regulation, and River Fragmentation (Table 1). Even though results of all other indicators, including the factor reservoir size (surface area), did not differ significantly between LHP and SHP, mean values of normalized indicators were always higher for SHP.

Table 1. Results of Mann-Whitney U Test for independent variables. Cumulated impacts differed significantly between small (SHP) and large hydropower plants (LHP) in four out of 9 indicators (including reservoir size). Mean values of normalized indicators were always higher for SHP.

\begin{tabular}{|c|c|c|c|c|}
\hline \multirow{2}{*}{ Indicator Normalized to $1 \mathrm{MW}$} & \multirow{2}{*}{ Mann-Whitney U } & \multirow{2}{*}{$p$-Value } & \multicolumn{2}{|c|}{ Mean Value (Indicator/MW) } \\
\hline & & & SHP & LHP \\
\hline Reservoir Size $\left[\mathrm{km}^{2} / \mathrm{MW}\right]$ & 166 & 0.584 & 481,801 & 212,613 \\
\hline River Regulation [\%/MW] & 33 & $<0.001^{* *}$ & 45 & 4 \\
\hline River Fragmentation [\%/MW] & 27 & $<0.001^{* *}$ & 16 & 1 \\
\hline Resettlement [No/MW] & 160 & 0.584 & 59 & 28 \\
\hline Land Use Change-Agriculture $\left[\mathrm{km}^{2} / \mathrm{MW}\right]$ & 265 & 0.057 & 276,670 & 178,946 \\
\hline Land Use Change-Vegetation Cover $\left[\mathrm{km}^{2} / \mathrm{MW}\right]$ & 103.5 & 0.035 * & 186,339 & 20,752 \\
\hline Sediment Entrapment [years/MW] & 30 & $<0.001^{* *}$ & 8385 & 24 \\
\hline Potential Evaporation $\left[\mathrm{m}^{3} / \mathrm{MW}\right]$ & 174 & 0.725 & 450,667 & 200,670 \\
\hline Protected Areas $\left[\mathrm{km}^{2} / \mathrm{MW}\right]$ & 158.5 & 0.426 & 96,965 & 14,921 \\
\hline
\end{tabular}

$* \leq 5 \%,{ }^{* *} \leq 0.1 \%$, (level of significance).

Figure 7, for example, illustrates the distribution of river regulation normalized to capacity caused by small and large HPP in the Vjosa catchment. In contrast to LHP, impacts of SHP are broadly distributed and often exceed impacts of LHP (Figure 7).

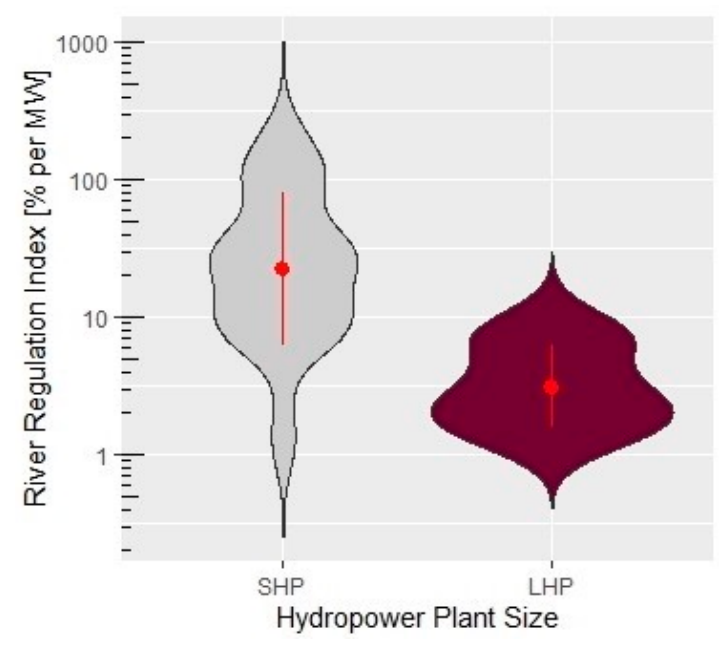

Figure 7. Impacts on river regulation (RRI), normalized to capacity, for all small (SHP, gray) and large (LHP, purple) hydropower plants. Mean \pm standard deviation is shown as red error bar.

LHP and SHP characteristics and impacts normalized to HPP capacity [MW] are listed in the Supplementary Materials (Table S4).

\section{Discussion}

Hydropower development is subject to major discussions. Standardized impact assessments to assess the diverse ecological, social, and economic impacts of planned HPP on a catchment scale are scarce. If impact assessments are obligatory due to regional regulations, they are carried out for individual cases (e.g., EIA). Potential impacts of planned SHP are usually not assessed at all $[37,69]$. Indeed, integrated catchment scale impact assessments including planned SHP and LHP are of utmost importance to assess 
potential impacts of planned HPP, because rivers are connected systems. Only if the entire river catchment is considered as a connected system in an impact assessment can sustainable hydropower planning be achieved. The present case study provides basic knowledge to quantify an integrated impact assessment for the Vjosa catchment.

In Europe, hydropower planning along the Vjosa is controversially discussed because recent studies have outlined the manifold environmental impacts of the planned HPP on one of the least modified continental river systems [42,70]. At the same time, the planned HPP Poçem and Kalivaç are considered as important renewable energy suppliers for the entire region $[69,71]$. A recently published review demonstrated that the EIA study for the HPP Kalivaç is based on insufficient data. At the same time, fundamental environmental threats and impacts are not covered at all [72].

The present case study contributes important information to the discussion on sustainable hydropower development, using the Vjosa catchment as a case study. By integrating ecological, social, and economic indicators for all planned HPP in the Vjosa catchment, our results allow comparisons between individual projects considering their specific impacts as well as the capacity they will provide.

Focusing on HPP with low social and environmental impacts, capacity size does play a role, as all planned HPP within the lowest and lower-middle quartile will only generate capacities up to $10 \mathrm{MW}$ and are thus considered SHP (Figure 4). Many SHP are needed to generate the energy a single LHP would generate. In the Vjosa catchment, the lowest ranked LHP Kosina (35 MW) and Grabova (50 MW) would generate more capacity than all planned SHP ranked in the lowest quartile together (16 SHP, $71.7 \mathrm{MW}$, Appendix A, Table S3). The critically discussed HPP Poçem (102 MW) and Kalivaç (100 MW) would cause major negative environmental impact (upper-middle quartile). However, compared to other planned HPP, they would generate a significant amount of energy (202 MW, Appendix A, Table S3).

The results reveal a general correlation between capacity and impact; however, large impacts can result from small capacity sizes, which again highlights the importance of a site-specific context. The 12 planned HPP with a very high impact each vary in capacity from 1 to $130 \mathrm{MW}$, with projected reservoir areas ranging from 1 to $53 \mathrm{~km}^{2}$. Considering location, the present assessment predicted devastating ecological, social, and economic impacts of HPP located in the Greek catchment. This mountainous region is characterized by Natura 2000 and other protected areas, which would be affected by planned HPP. Additionally, the high density of planned HPP along the upper Vjosa and its tributaries would lead to a high degree of river fragmentation and regulation.

While it is mandatory for planned LHP to carry out an EIA, impacts of SHP are often neglected or underestimated during the planning process, which again may harm the environment, society, and economy [30,73]. To our knowledge, integrated impact assessments on the catchment scale are lacking. The present impact assessment enables comparison of the manifold ramifications of all planned HPP, which again supports decision-makers in weighing pros and cons when deciding on future hydropower dam locations. Even though the Eco-Masterplan for Balkan Rivers realized an impact assessment for the Balkan Region, it only considered ecological impacts, similar to the scenario "Conservationist" created in this study.

The results of the impact assessment considering different indicator compositions highlighted that an overall ranking is dependent upon the selection and composition of indicators. Even though due to feasibility reasons the number of included indicators was limited, and the created scenarios (Conservationist, Economist, Climate Protector) empirically developed, the scenarios "Conservationist" and "Economist" supported a trend that real-life scenarios are showing too. Namely, the Eco-Masterplan for Balkan Rivers concluded that the entire Vjosa River system should be a "No-Go"-Area for hydropower. This specific assessment focused on indicators of nature-conserving interest [41]. However, an EIA realized for two planned HPP in the region and commissioned by a company that constructs HPP came to different conclusions [69]. Through the inclusion of social 
and economic indicators, they found that the "positive impacts [of building specific HPP] are far more numerous than the negative ones" [69]. One reason that could possibly explain these opposing conclusions is the selection of the indicators to be considered in the assessment. The different scenarios "Conservationist" and "Economist" came to opposing rankings because different indicators were included (Figure 5). Even though it is important to consider restrictions and limits of the present study, our results show that inclusion or exclusion of impact indicators might change a ranking. If impact assessments are not standardized, stakeholders of different interests might unconsciously prioritize and include specific indicators in their assessments, which is likely to have a pronounced effect on the overall impact assessment and ranking of planned HPP.

Taking the Vjosa catchment as an example, our results demonstrate the necessity of catchment scale impact assessments for planned SHP and LHP in order to facilitate sustainable planning. Furthermore, it is strongly recommended to include a sensitivity analysis, as results are likely to change with selected indicators and indicator compositions. In this study, only river regulation and fragmentation included upstream and downstream alterations of the flow regime, while all other indicators were dependent on the projected reservoir size. Interactions, cumulative effects, and off-site impacts as well as specific management strategies (e.g., sediment flushing) were not considered. Indicators were selected according to data availability and were mainly of ecological relevance. To this point, other studies demonstrated that political and socioeconomic indicators provide important information [74]. Additionally, cost-benefit analyses are useful too and, therefore, frequently employed in models [75]. Calculation of direct indicators and a cost-benefit analysis would be required for future research to complement the impact assessment for the Vjosa. However, these limitations are case based, and it would be possible to include additional indicators in the used methodological approach. Consequently, the integrated methodological approach used in this study is transferable and can be applied in different spatial and temporal contexts to improve sustainable hydropower planning. A set of indicators should be elaborated and selected by stakeholders of different interests to ensure that ecological, social, and economic impacts are adequately addressed.

Considering the size selection, our study adds information to an ongoing global discussion on cumulative impacts of many small vs. several large HPP. The boom of small hydropower construction is also key to the development along the Vjosa. Our comparison showed higher cumulative impacts for SHP, with half of the indicators being statistically significant. This comparably low significance level can be explained by small differences in capacity size between SHP and LHP due to the European size definition of hydropower (SHP $\leq 10 \mathrm{MW}$ ) and a small catchment size. It underlines the necessity of a global standardized definition for large and small hydropower; for SHP, capacity definitions range from $\leq 10 \mathrm{MW}$ in Europe to $\leq 50 \mathrm{MW}$ in China and make it difficult to apply research and assessment outputs to a global scale. Despite these limitations, our results are consistent with results of other studies, and they challenge the assumption that SHP have low or even no negative ecological, social, or economic impacts [25,31-35,73]. Furthermore, LHP are more likely to withstand variabilities in streamflow caused by fluctuating water levels over short time periods (Hurst-Kolmogorov behavior) [76-79]. These natural variabilities will even increase as climate change influences the regional water budget [80]. Decision-makers have to consider that the probability of failure might be higher for SHP when deciding between large and small HPP [81].

\section{Conclusions}

In the Vjosa catchment, the number of HPP would increase from 20 (present state) to 71 if all planned HPP were constructed. The total capacity would even increase from 93 to 983 MW. Hence, the planned dams may threaten the Vjosa as one of the last near-natural rivers remaining in Europe.

Based on the results of the impact assessment and considering planned capacity, construction of all SHP (1-10 MW each) ranked in the upper-middle and top quartile is 
critical and should be avoided (Figure 4). This affects 16 out of 42 SHP in total, 15 on Albanian and one on Greek territory.

As there are no planned HPP with capacities exceeding $10 \mathrm{MW}$ within the lowest and lower-middle quartile, their construction must be evaluated on a case-by-case basis. LHP such as Kosina ( $35 \mathrm{MW}$ ) and Grabova (50 MW), which exhibit low to moderate impact ranks, may serve as alternative options considering trade-offs between energy production and socioenvironmental impacts. The sensitivity analysis revealed that the overall ranking of an HPP is related to the indicator selection. The scenarios "Conservationist" and "Economist", for example, showed opposing ranking outputs. HPP rankings of impact assessments thus depend on indicator selection. To avoid stakeholders with different interests selecting a set of indicators that may lead to their most favored outcomes (i.e., self-fulfilling results), standardized and comparable impact assessment procedures are of utmost importance.

The comparison of small and large HPP showed that SHP exhibited higher cumulative effects (all indicators) which is in line with findings from other studies [31-35].

In conclusion, the following recommendations for decision-makers can be made:

- Impact assessments, applying a comparable set of criteria, should be carried out for both SHP and LHP. It is crucial to consider the additive/synergistic impacts of HPP, especially of SHP within (sub-)catchments;

- Impact assessments should include a sensitivity analysis because ranking of planned HPP might change with impact indicators included. Policymakers should be aware of the role indicator selection has on impact ranking;

- When deciding for SHP or LHP, future capacity potential should be considered. SHP are likely to generate higher impacts per installed MW. In addition, SHP have less capabilities to withstand climatic fluctuations (e.g., increased drought frequency induced by climate change).

Currently, hydropower is considered the most economical and efficient technique to provide renewable energy and thus help mitigate climate change. The present study offers a transferable integrated approach to enable sustainable hydropower planning, while considering site and size characteristics. Still, it is of pivotal importance to carefully evaluate if hydropower remains the most suitable and sustainable option. Both, Albania and Greece, are already highly dependent on energy from hydropower, and this dependence would strongly increase if planned HPP were realized. Considering climate change scenarios for the Vjosa catchment, an expected decrease in precipitation would further increase the pressure on hydropower energy supply [82]. To favor simultaneously resilient renewable energy development and protection of one of the last near-natural rivers in Europe, future research (and management actions) should not only focus on sustainable planning of hydropower as a well-established technology, but consider alternative renewable energy resources to broaden the regional energy portfolio.

Supplementary Materials: The following data and information are available online at https:/ /www. mdpi.com/2071-1050/13/3/1514/s1. S1. Calculation of single indicators (mathematical formulas); Table S2. Absolute impacts of hydropower plants in each indicator; Table S3. Ranking of planned hydropower plants per indicator and overall as a sum of the indicators in quartiles; Table S4. Hydropower plant (HPP) characteristics and impacts normalized to HPP capacity [MW]; Table S5. Spearman's correlation coefficients for correlations between the individual indicators. Color intensifies with decreasing degree of correlation; Table S6. Land use changes-area of different land use types affected by projected reservoir areas; Figure S7. Results of impact assessment for the indicator River Regulation (RRI: River Regulation Index); Figure S8. Results of impact assessment for the indicator River Fragmentation (RFI: River Fragmentation Index); Figure S9. Results of impact assessment for the indicators Land Use Change-Agriculture (LUC-A) and Land Use ChangeVegetation Cover (LUC-V; including forest; grassland; and shrubland); Figure S10. Results of impact assessment for the indicator Resettlement: Circles indicate planned (gray) hydropower plants (HPP); Figure S11. Results of impact assessment for the indicator Protected Area; Figure S12. Results of impact assessment for the indicator Sediment Entrapment; Figure S13. Results of impact assessment for the indicator Potential Evaporation. 
Author Contributions: R.P. C.Z., and J.B. conceptualized and led the study; R.P. performed the analysis with essential support from R.P., C.Z., J.B., K.T., V.S.; and A.L., substantially contributed to the interpretation of the results; R.P. wrote the initial draft of the manuscript and all co-authors revised the work carefully. All authors have read and agreed to the published version of the manuscript.

Funding: This research received no external funding.

Institutional Review Board Statement: Not applicable.

Informed Consent Statement: Not applicable.

Data Availability Statement: The data presented in this study are available in Appendix A and Supplementary Materials.

Acknowledgments: C.Z. and R.P. acknowledge the funding through the Excellence Initiative at the University of Tübingen, funded by the German Research Foundation (DFG) and the BMBF. We also acknowledge financial support by the DFG and the Open Access Publishing Fund of the University of Tübingen.

Conflicts of Interest: The authors declare no conflict of interest.

\section{Appendix A. Hydropower Plants (HPP), their Location and their Characteristics}

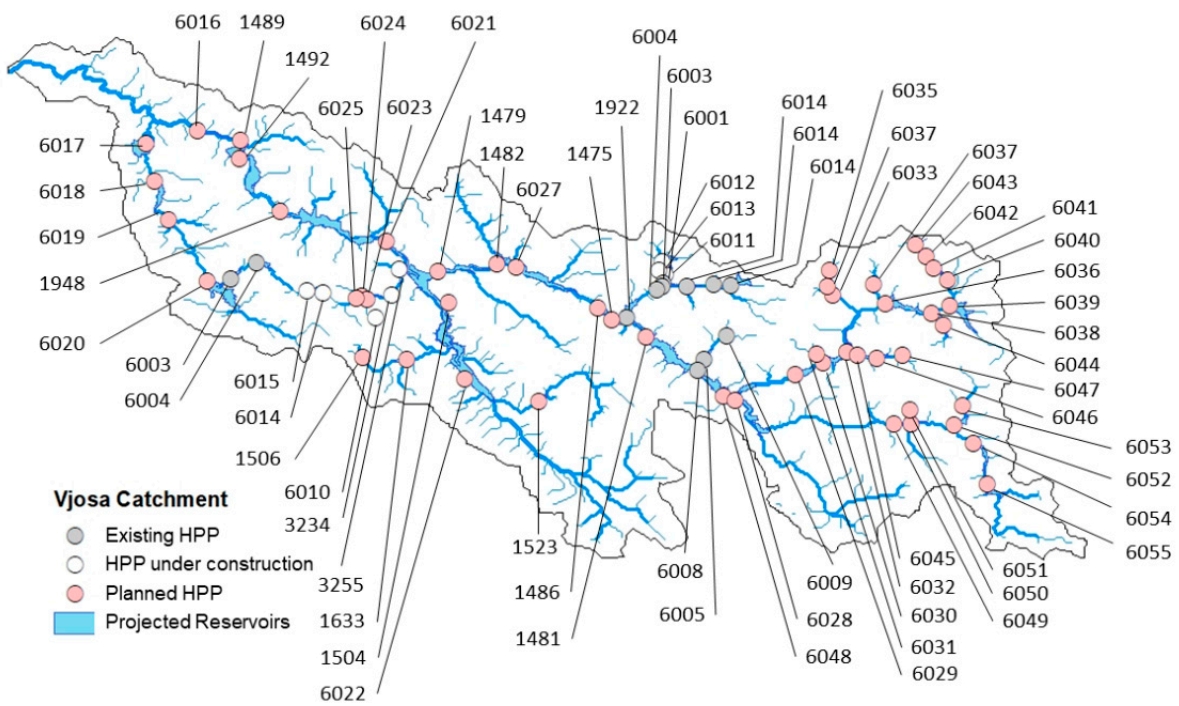

Figure A1. Location of existing (including under construction) and planned hydropower plants in the Vjosa catchment. IDs (identifiers) refer to further characteristics given in Table A1.

Table A1. Characteristics of existing, under construction, or planned hydropower plants in the Vjosa catchment. Reservoir area and size have been estimated based on the capacity given [49]. The location of the dams and their associated reservoirs are given in Figure A1.

\begin{tabular}{|c|c|c|c|c|c|c|}
\hline ID & Name & Country & Capacity [MW] & Stage & Reservoir Area $\left[\mathrm{m}^{2}\right]$ & Reservoir Volume [Mio $\mathrm{m}^{3}$ ] \\
\hline 1911 & Barmash & Albania & 3 & Existing & 3412127 & 116.15 \\
\hline 1922 & Langarica 3 & Albania & 28.4 & Existing & 3173810 & 133.34 \\
\hline 6000 & Rajan 1 & Albania & 3.7 & Existing & 1609847 & 52.42 \\
\hline 6001 & Rajan 2 & Albania & 3.26 & Existing & 1503251 & 46.17 \\
\hline 6002 & Lengarica (Ura e Darshit) & Albania & 1.2 & Existing & 120474 & 1.54 \\
\hline 6003 & Langarice 1 & Albania & 3.7 & Existing & 1223882 & 27.61 \\
\hline 6004 & Langarice 2 & Albania & 2.5 & Existing & 918522 & 16.33 \\
\hline 6005 & Radove & Albania & 2 & Existing & 940899 & 27.34 \\
\hline 6006 & Smokthine 2 & Albania & 4.6 & Existing & 1276104 & 79.60 \\
\hline 6007 & Smokthine 1 & Albania & 4.6 & Existing & 1460451 & 24.28 \\
\hline 6008 & Carshove & Albania & 1.5 & Existing & 18181372 & 429.91 \\
\hline 6009 & Leskovik 2 & Albania & 1.1 & Existing & 401211 & 9.90 \\
\hline 3234 & Bence & Albania & 2.07 & Under Construction & 636003 & 11.62 \\
\hline 3255 & Tepelene & Albania & 5.42 & Under Construction & 794078 & 20.43 \\
\hline 6010 & Progonat-Lekdush & Albania & 4 & Under Construction & 107488 & 1.53 \\
\hline 6011 & Gostivisht (Lengarica3) & Albania & 6.2 & Under Construction & 4620668 & 245.00 \\
\hline 6012 & Gostivisht & Albania & 1.3 & Under Construction & 221377 & 4.12 \\
\hline 6013 & Ura e Darshit & Albania & 1.44 & Under Construction & 587199 & 10.85 \\
\hline 6014 & Kendrevica 1 & Albania & 2.7 & Under Construction & 2647030 & 155.27 \\
\hline 6015 & Kendrevica 2 & Albania & 10 & Under Construction & 2223853 & 102.83 \\
\hline
\end{tabular}


Table A1. Cont.

\begin{tabular}{|c|c|c|c|c|c|c|}
\hline ID & Name & Country & Capacity [MW] & Stage & Reservoir Area $\left[\mathrm{m}^{2}\right]$ & Reservoir Volume $\left[\mathrm{Mio} \mathrm{m}^{3}\right]$ \\
\hline 1475 & Badëlonje & Albania & 30 & Planned & 4335638 & 66.47 \\
\hline 1479 & Dragot & Albania & 130 & Planned & 53102166 & 1187.22 \\
\hline 1481 & Kaludhi & Albania & 75 & Planned & 34245503 & 1198.28 \\
\hline 1482 & Kosina & Albania & 35 & Planned & 5916653 & 69.99 \\
\hline 1486 & Përmet & Albania & 25 & Planned & 3612754 & 40.84 \\
\hline 1489 & Karbonara & Albania & 60 & Planned & 5058927 & 31.85 \\
\hline 1492 & Poçem & Albania & 102 & Planned & 14007837 & 51.87 \\
\hline 1504 & Ura e Subashit & Albania & 10 & Planned & 10350309 & 108.71 \\
\hline 1506 & Kapariel & Albania & 2 & Planned & 133350 & 2.42 \\
\hline 1523 & Suha 2 & Albania & 3.4 & Planned & 601358 & 12.33 \\
\hline 1633 & Kolonje 2 & Albania & 2 & Planned & 1430607 & 32.40 \\
\hline 1948 & Kalivaç & Albania & 100 & Planned & 20599265 & 437.44 \\
\hline 6016 & Selenica & Albania & 10 & Planned & 1153386 & 5.92 \\
\hline 6017 & Vernik 4 & Albania & 2.2 & Planned & 6293595 & 22.67 \\
\hline 6018 & Vernik 3 & Albania & 6.4 & Planned & 4135991 & 42.24 \\
\hline 6019 & Kote & Albania & 1.7 & Planned & 330199 & 0.94 \\
\hline 6020 & Brataj & Albania & 10 & Planned & 10208028 & 164.13 \\
\hline 6021 & Memeliaj & Albania & 10 & Planned & 3610583 & 19.87 \\
\hline 6022 & Suha 1 & Albania & 2.4 & Planned & 7125316 & 38.22 \\
\hline 6023 & Nivice & Albania & 1 & Planned & 65846 & 0.46 \\
\hline 6024 & Driza 2 & Albania & 2.2 & Planned & 134556 & 3.17 \\
\hline 6025 & Driza 1 & Albania & 2.1 & Planned & 244599 & 5.34 \\
\hline 6027 & Grabova & Albania & 50 & Planned & 8135706 & 111.27 \\
\hline 6028 & Mesare & Albania & 1 & Planned & 695501 & 2.56 \\
\hline 6029 & NN1 & Greece & 10 & Planned & 2251480 & 40.33 \\
\hline 6030 & NN3 & Greece & 10 & Planned & 3407385 & 71.51 \\
\hline 6031 & NN4 & Greece & 10 & Planned & 695174 & 20.88 \\
\hline 6032 & NN5 & Greece & 1 & Planned & 1646083 & 29.98 \\
\hline 6033 & NN7 & Greece & 1 & Planned & 958112 & 25.58 \\
\hline 6034 & NN8 & Greece & 1 & Planned & 529996 & 14.89 \\
\hline 6035 & NN9 & Greece & 10 & Planned & 903289 & 36.75 \\
\hline 6036 & NN10 & Greece & 10 & Planned & 6131323 & 244.73 \\
\hline 6037 & NN11 & Greece & 10 & Planned & 389642 & 9.34 \\
\hline 6038 & NN12 & Greece & 10 & Planned & 2270945 & 133.65 \\
\hline 6039 & NN13 & Greece & 10 & Planned & 6554585 & 260.52 \\
\hline 6040 & NN15 & Greece & 10 & Planned & 912627 & 18.99 \\
\hline 6041 & NN16 & Greece & 10 & Planned & 1201605 & 37.44 \\
\hline 6042 & NN17 & Greece & 10 & Planned & 1116450 & 31.83 \\
\hline 6043 & NN18 & Greece & 10 & Planned & 1784935 & 83.77 \\
\hline 6044 & NN19 & Greece & 10 & Planned & 520999 & 11.99 \\
\hline 6045 & NN20 & Greece & 10 & Planned & 1590415 & 59.60 \\
\hline 6046 & NN21 & Greece & 10 & Planned & 978742 & 36.22 \\
\hline 6047 & NN22 & Greece & 1 & Planned & 910987 & 6.28 \\
\hline 6048 & NN23 & Greece & 10 & Planned & 6771385 & 80.13 \\
\hline 6049 & NN25 & Greece & 1 & Planned & 466383 & 4.70 \\
\hline 6050 & NN26 & Greece & 10 & Planned & 754380 & 21.68 \\
\hline 6051 & NN27 & Greece & 1 & Planned & 25884 & 0.56 \\
\hline 6052 & NN28 & Greece & 10 & Planned & 1699349 & 78.64 \\
\hline 6053 & NN30 & Greece & 10 & Planned & 534176 & 23.34 \\
\hline 6054 & NN31 & Greece & 10 & Planned & 2513854 & 84.83 \\
\hline 6055 & NN32 & Greece & 10 & Planned & 2997797 & 150.97 \\
\hline
\end{tabular}

\section{References}

1. International Energy Agency. World Energy Outlook: Executive Summary; OECD: Paris, France; IEA: Paris, France, 2018.

2. Ballantyne, A.P.; Alden, C.B.; Miller, J.B.; Tans, P.P.; White, J.W.C. Increase in observed net carbon dioxide uptake by land and oceans during the past 50 years. Nature 2012, 488, 70-72. [CrossRef] [PubMed]

3. Brandi, C.; Dzebo, A.; Janetschek, H.; Lambert, C.; Savvidou, G. NDC-SDG Connections. Available online: https://klimalog.diegdi.de/ndc-sdg/ (accessed on 10 March 2020).

4. Wagner, B.; Hauer, C.; Habersack, H. Current hydropower developments in Europe. Curr. Opin. Environ. Sustain. 2019, 37, 41-49. [CrossRef]

5. Zarfl, C.; Lumsdon, A.E.; Berlekamp, J.; Tydecks, L.; Tockner, K. A global boom in hydropower dam construction. Aquat. Sci. 2014, 77, 161-170. [CrossRef]

6. Grill, G.; Lehner, B.; Thieme, M.; Geenen, B.; Tickner, D.; Antonelli, F.; Babu, S.; Borrelli, P.; Cheng, L.; Crochetiere, H.; et al. Mapping the world's free-flowing rivers. Nature 2019, 569, 215-221. [CrossRef] [PubMed]

7. Zarfl, C.; Lucía, A. The connectivity between soil erosion and sediment entrapment in reservoirs. Curr. Opin. Environ. Sci. Health 2018, 5, 53-59. [CrossRef]

8. Grant, G.E.; Schmidt, J.C.; Lewis, S.L. A geological framework for interpreting downstream effects of dams on rivers. Water Sci. Appl. 2003, 7, 209-225.

9. Deemer, B.R.; Harrison, J.A.; Li, S.; Beaulieu, J.J.; Delsontro, T.; Barros, N.; Bezerra-Neto, J.F.; Powers, S.M.; Dos Santos, M.A.; Vonk, J.A. Greenhouse Gas Emissions from Reservoir Water Surfaces: A New Global Synthesis. Bioscience 2016, 66. [CrossRef] 
10. He, F.; Zarfl, C.; Bremerich, V.; Henshaw, A.; Darwall, W.; Tockner, K.; Jähnig, S.C. Disappearing giants: A review of threats to freshwater megafauna. Wiley Interdiscip. Rev. Water 2017, 4, e1208. [CrossRef]

11. Carrizo, S.F.; Jähnig, S.C.; Bremerich, V.; Freyhof, J.; Harrison, I.; He, F.; Langhans, S.D.; Tockner, K.; Zarfl, C.; Darwall, W. Freshwater Megafauna: Flagships for Freshwater Biodiversity under Threat. Bioscience 2017, 67, 919-927. [CrossRef]

12. Wu, H.; Chen, J.; Xu, J.; Zeng, G.; Sang, L.; Liu, Q.; Yin, Z.; Dai, J.; Yin, D.; Liang, J. Effects of dam construction on biodiversity: A review. J. Clean. Prod. 2019, 221, 480-489. [CrossRef]

13. Tilt, B.; Braun, Y.; He, D. Social impacts of large dam projects: A comparison of international case studies and implications for best practice. J. Environ. Manag. 2009. [CrossRef] [PubMed]

14. Bartolome, L.J.; Danklmaier, C.M.; Hemadri, R.; Bandh, B.; Samiti, S.; Jing, I.J. Displacement, Resettlement, Rehabilitation, Reparation, and Development; World Comission on Dams: Cape Town, South Africa, 2000.

15. Bilson Obour, P.; Owusu, K.; Agyeman, E.A.; Ahenkan, A.; Madrid, N.À. The impacts of dams on local livelihoods: A study of the Bui Hydroelectric Project in Ghana. Int. J. Water Resour. Dev. 2016, 32, 286-300. [CrossRef]

16. Opperman, J.J.; Hartmann, J.; Raepple, H.; Angarita, P.; Beames, E.; Chapin, R.; Geressu, G.; Grill, J.; Harou, A.; Hurford, D.; et al. The Power of Rivers: A Business Case; The Nature Consefvancy: Washington, DC, USA, 2017.

17. Lerer, L.B.; Scudder, T. Health impacts of large dams. Envrion. Impact Assess. Rev. 1999, 19, 113-123. [CrossRef]

18. Tuan, T.A.; Purnachandra Rao, N.; Gahalaut, K.; Trong, C.D.; Van Dung, L.; Chien, C.; Mallika, K. Evidence that earthquakes have been triggered by reservoir in the Song Tranh 2 region, Vietnam. J. Seismol. 2017, 21, 1131-1143. [CrossRef]

19. von Lossow, T. Flüsse und Konflikte. Rundbr. Forum Umwelt Entwicklung. 2018. Available online: https://www.forumue.de/ wp-content/uploads/2019/01/05_Fl\%C3\%BCsse-imd-Konflikte_Lossow.pdf (accessed on 29 January 2021).

20. Ioannidis, R.; Koutsoyiannis, D. A review of land use, visibility and public perception of renewable energy in the context of landscape impact. Appl. Energy 2020, 276, 115367. [CrossRef]

21. Zawahri, N.A.; McLaughlin Mitchell, S. Fragmented Governance of International Rivers: Negotiating Bilateral versus Multilateral Treaties. Int. Stud. Q. 2011, 55, 835-858. [CrossRef]

22. Apadula, F.; Bassini, A.; Elli, A.; Scapin, S. Relationships between meteorological variables and monthly electricity demand. Appl. Energy 2012. [CrossRef]

23. Chen, S.; Chen, B.; Su, M. The cumulative effects of dam project on river ecosystem based on multi-scale ecological network analysis. Procedia Environ. Sci. 2011. [CrossRef]

24. Gergel, S.E. Assessing cumulative impacts of levees and dams on floodplain ponds: A neutral-terrain model approach. Ecol. Appl. 2002, 12, 1740-1754. [CrossRef]

25. Kelly-Richards, S.; Silber-Coats, N.; Crootof, A.; Tecklin, D.; Bauer, C. Governing the transition to renewable energy: A review of impacts and policy issues in the small hydropower boom. Energy Policy 2017, 101, 251-264. [CrossRef]

26. Gunawardena, U.A.D.P. Inequalities and externalities of power sector: A case of Broadlands hydropower project in Sri Lanka. Energy Policy 2010, 38, 726-734. [CrossRef]

27. Stone, R. Hydropower. The legacy of the Three Gorges Dam. Science 2011, 333, 817. [CrossRef] [PubMed]

28. Ziv, G.; Baran, E.; Nam, S.; Rodríguez-Iturbe, I.; Levin, S.A. Trading-off fish biodiversity, food security, and hydropower in the Mekong River Basin. Proc. Natl. Acad. Sci. USA 2012, 109, 5609-5614. [CrossRef] [PubMed]

29. Sovacool, B.K.; Bulan, L.C. Behind an ambitious megaproject in Asia: The history and implications of the Bakun hydroelectric dam in Borneo. Energy Policy 2011, 39, 4842-4859. [CrossRef]

30. Ansar, A.; Flyvbjerg, B.; Budzier, A.; Lunn, D. Should we build more large dams? The actual costs of hydropower megaproject development. Energy Policy 2014, 69, 43-56. [CrossRef]

31. Zeleňáková, M.; Fijko, R.; Diaconu, D.; Remeňáková, I. Environmental Impact of Small Hydro Power Plant-A Case Study. Environments 2018, 5, 12. [CrossRef]

32. Gleick, P.H. Environmental consequences of hydroelectric development: The role of facility size and type. Energy 1992, 17, 735-774. [CrossRef]

33. Bakken, T.H.; Sundt, H.; Ruud, A.; Harby, A. Development of small versus large hydropower in Norway comparison of environmental impacts. Energy Procedia 2012. [CrossRef]

34. Kibler, K.M.; Tullos, D.D. Cumulative biophysical impact of small and large hydropower development in Nu River, China. Water Resour. Res. 2013, 49, 3104-3118. [CrossRef]

35. Mayor, B.; Rodríguez-Muñoz, I.; Villarroya, F.; Montero, E.; López-Gunn, E. The role of large and small scale hydropower for energy and water security in the Spanish Duero basin. Sustainability 2017, 9, 1807. [CrossRef]

36. Gallop, P.; Vejnović, I.; Pehchevski, D. Western Balkans Hydropower. Who Pays, Who Profits? EuroNatur: European Nature Heritage Foundation, Riverwatch: Society for the Protection of Rivers. 2019. Available online: https://bankwatch.org/wpcontent/uploads/2019/09/who-pays-who-profits.pdf (accessed on 25 November 2019).

37. Susaj, E.; Kucaj, E.; Qaja, B. Assessment of possible effects on ecosystems of small hydropower plants under construction in Valbona Valley National Park, Albania. Paper presented at TAW 2018 International Scientific Conference: [CO] Habitation Tactics. Imagining Future Spaces in Architecture, City and Landscape, Polis University, Tirana, Albania, 20-23 September 2018.

38. International Hydropower Association (IHA). Hydropower Sustainability Assessment Protocol. 2018. Available online: https: //www.hydrosustainability.org/assessment-protocol (accessed on 15 October 2020). 
39. Internation Rivers. Greenwashing Dams: A Critique of the Hydropower Sustainability Assessment Protocol (HSAP). 2013. Available online: https://www.internationalrivers.org/wp-content/uploads/sites/86/2020/05/hsapfactsheet2013.pdf (accessed on 10 January 2020).

40. Liden, R.; Lyon, K. The Hydropower Sustainability Assessment Protocol for Use by World Bank Clients: Lessons Learned and Recommendations; World Bank: Washington, DC, USA, 2014; Available online: https://openknowledge.worldbank.org/handle/10986/19990 (accessed on 11 January 2020).

41. Schwarz, U.; Graf, W.; Weiss, S.; Lopes-Lima, M.; Chamberlain, L. Eco-Masterplan for Balkan Rivers; Riverwatch: Vienna, Austria; EuroNatur: Radolfzell, Germany, 2018.

42. Schiemer, F.; Drescher, A.; Hauer, C.; Schwarz, U. The Vjosa River corridor: A riverine ecosystem of European significance. Acta Zoobot Austria 2018, 155, 1-40.

43. Durmishi, Ç.; Daja, S.; Ago, B.; Dindi, E.; Sinojmeri, A.; Nazaj, S.; Qorri, A.; Muçi, R. Synthesis of geological, hydrogeological, and geo-touristic features of the Vjosa Watershed. Acta Zoobot Austria 2018, 155, 41-61.

44. Shumka, S.; Bego, F.; Beqiraj, S.; Paparisto, A. The Vjosa catchment-A natural heritage. Acta Zoobot Austria 2018, 155, 349-376.

45. Schiemer, F.; Beqiraj, S.; Drescher, A.; Graf, W.; Egger, G.; Essl, F.; Frank, T.; Hauer, C.; Hohensinner, S.; Miho, A.; et al. The Vjosa River corridor: A model of natural hydro-morphodynamics and a hotspot of highly threatened ecosystems of European significance. Landsc. Ecol. 2020, 35, 953-968. [CrossRef]

46. EuroNatur; Riverwatch. Save the Blue Heart of Europe. Background. Available online: https://balkanrivers.net/en/campaign (accessed on 6 June 2019).

47. EuroNatur; Riverwatch. Vision for Vjosa: Europe's 1st Wild River National Park! Available online: https:/ /balkanrivers.net/ sites/default/files/TheVjosaWRNP_factsheet.pdf (accessed on 20 March 2020).

48. Lehner, B.; Liermann, C.R.; Revenga, C.; Vörösmarty, C.; Fekete, B.; Crouzet, P.; Döll, M.; Endejan, K.; Frenken, J.; Magome, J.; et al. High-resolution mapping of the world's reservoirs and dams for sustainable river-flow management. Front. Ecol. Environ. 2011, 9, 494-502. [CrossRef]

49. Mulligan, M.; Saenz, L.; van Soesbergen, A.; Smith, V.T.; Zurita, L. Global Georeferenced Database of Dams. Glob. Dams Database Geowiki. Version 1. 2019. Available online: http:/ /geodata.policysupport.org/dams (accessed on 1 October 2019).

50. Stefani, V. Assessing Catchment-Scale Impacts of Hydropower on Sediment Transport in Vjosa river. Master's Thesis, Università degli studi di Trento, Trento, Italy, 2019.

51. ESRI. ArcGIS Desktop. ESRI, 2019. Available online: https://desktop.arcgis.com/en/ (accessed on 10 August 2019 ).

52. Grill, G.; Ouellet Dallaire, C.; Fluet Chouinard, E.; Sindorf, N.; Lehner, B. Development of new indicators to evaluate river fragmentation and flow regulation at large scales: A case study for the Mekong River Basin. Ecol. Indic. 2014. [CrossRef]

53. Lehner, B.; Verdin, K.; Jarvis, A. HydroSHEDS Technical Documentation, version 1.0; World Wildl. Fund US: Washington, DC, USA, 2006; pp. 1-27. Available online: https:/ / www.hydrosheds.org/ (accessed on 10 October 2019).

54. Lehner, B. HydroBASINS. 2014. Available online: https://www.hydrosheds.org/ (accessed on 10 October 2019).

55. Döll, P.; Lehner, B. Validation of a new global 30-min drainage direction map. J. Hydrol. 2002, 258, 214-231. [CrossRef]

56. Wischmeier, W.H.; Smith, D.D. Predicting Rainfall Erosion Losses: A Guide to Conservation Planning; Science and Education Administration United States Department of Agriculture incooperation with Purdue Agricultural Experiment Station: Washington, DC, USA, 1978.

57. Renard, K.G.; Foster, G.R.; Yoder, D.C.; McCool, D.K. RUSLE revisited: Status, questions, answers, and the future. J. Soil Water Conserv. 1994, 49, 213-220.

58. Cavalli, M.; Trevisani, S.; Comiti, F.; Marchi, L. Geomorphometric assessment of spatial sediment connectivity in small Alpine catchments. Geomorphology 2013, 188, 31-41. [CrossRef]

59. Döll, P.; Kaspar, F.; Lehner, B. A global hydrological model for deriving water availability indicators: Model tuning and validation. J. Hydrol. 2003, 270, 105-134. [CrossRef]

60. Lehner, B.; Verdin, K.; Jarvis, A. New global hydrography derived from spaceborne elevation data. EosTrans. Geophys. Union 2008, 89, 93-94. [CrossRef]

61. Zarfl, C.; Berlekamp, J.; He, F.; Jähnig, S.C.; Darwall, W.; Tockner, K. Future large hydropower dams impact global freshwater megafauna. Sci. Rep. 2019, 9, 18531. [CrossRef] [PubMed]

62. UNEP-WCMC; IUCN. Protected Planet: World Database on Protected Areas (WDPA). Available online: www.protectedplanet.net (accessed on 2 February 2020).

63. ESA. Land Cover CCI Product User Guide Version 2. Tech. Rep.. 2017. Available online: Maps.elie.ucl.ac.be/CCI/viewer/ download/ESACCI-LC-Ph2-PUGv2_2.0.pdf (accessed on 10 April 2020).

64. WorldPop Data: Population Density (University of Southampton). Available online: www.worldpop.org (accessed on 8 December 2019).

65. Jippe Hoogeveen (FAO). Global Map of Monthly Reference Evapotranspiration-10 arc Minutes. Available online: http: / / www.fao.org/geonetwork/srv/en/main.home\#climate (accessed on 3 March 2020).

66. Saltelli, A.; Tarantola, S.; Campolongo, F.; Ratto, M. Sensitivity Analysis in Practice: A Guide to Assessing Scientific Models; Wiley Online Library: Hoboken, NJ, USA, 2004; Volume 1.

67. Middendorf, V. Impacts of Hydropower Dams-A Sensitivity Analysis for Integrating Indicators of Ecological and Societal Relevance. Master's Thesis, Eberhard Karls Universität, Tübingen, Germany, 2018. 
68. R Core Team. R: A Language and Environment for Statistical Computing; R Foundation for Statistical Computing: Vienna, Austria, 2020; Available online: https:/ / www.R-project.org/ (accessed on 5 January 2020).

69. Llupo, S.; Spahiu, S.; Ismaili, E.; Dhima, S.; Mansaku, R. Profoundal Environmental Impact Assessment Report for the Construction of HPP Pocem; GR Albania Environmental: Tirana, Albania, 2015.

70. Hauer, C.; Aigner, H.; Fuhrmann, M.; Holzapfel, P.; Rindler, R.; Pessenlehner, S.; Pucher, D.; Skrame, K.; Liedermann, M. Measuring of Sediment Transport and Morphodynamics at the Vjosa River/Albania. 2019. Available online: https://balkanrivers. net/sites/default/ files/Sediment\%20Study\%20Boku\%202019.pdf (accessed on 10 September 2020).

71. ABKONS. Përmbledhja Joteknike e Vnm-së Thelluar Projekti: Hidrocentrali i Kalivaçit. 2019. Available online: http:/ /kalivachpp. com/wp-content/uploads/2019/08/HP-Kalivac-Studimit-VNMS-Raporti.pdf (accessed on 9 September 2020).

72. Miho, P.A.; Qorri, A.; Paparisto, P.A.; Anton, P.; Gerken, P.B.; Pepa, B.; Durmishi, P.Ç.; Komposch, P.C.; Hauer, C.; Haring, P.E.; et al. Vjosa River: Review of the Main Environmental and Social Impact Assessment (ESIA) for the HPP Kalivaç. 2020. Available online: https:/ / balkanrivers.net/sites/default/files/Kalivac\%20EIA\%20criticism.pdf (accessed on 1 October 2020).

73. Opperman, J. The unexpectedly large impacts of small hydropower. Forbes Magazine. 10 August 2018. Available online: https:// www.forbes.com/sites/jeffopperman/2018/08/10/the-unexpectedly-large-impacts-of-small-hydropower/?sh=15515a6f7b9d (accessed on 1 August 2019).

74. de Faria, F.A.M.; Davis, A.; Severnini, E.; Jaramillo, P. The local socio-economic impacts of large hydropower plant development in a developing country. Energy Econ. 2017, 67, 533-544. [CrossRef]

75. Johansson, P.O.; Hakansson, C.; Kriström, B.; Leonardsson, K.; Lundqvist, H. Salmon and Hydropower: Dynamic Cost-Benefit Analysis. In Proceedings of the Fifth International Symposium on Ecohydraulics, Congress Proceedings, Madrid, Spain, 12-17 September 2004.

76. Hurst, H.E. Long-term storage capacity of reservoirs. Trans. Am. Soc. Civ. Eng. 1951, 116, 770-799.

77. Kantelhardt, J.W.; Rybski, D.; Zschiegner, S.A.; Braun, P.; Koscielny-Bunde, E.; Livina, V.; Havli, S.; Bunde, A. Multifractality of river runoff and precipitation: Comparison of fluctuation analysis and wavelet methods. Phys. A Stat. Mech. Its Appl. 2003, 330, 240-245. [CrossRef]

78. Kantelhardt, J.W.; Koscielny-Bunde, E.; Rybski, D.; Braun, P.; Bunde, A.; Havlin, S. Long-term persistence and multifractality of precipitation and river runoff records. J. Geophys. Res. Atmos. 2006, 111. [CrossRef]

79. Dimitriadis, P.; Koutsoyiannis, D. Stochastic synthesis approximating any process dependence and distribution. Stoch. Environ. Res. Risk Assess. 2018, 32, 1493-1515. [CrossRef]

80. Sutcliffe, J.; Hurst, S.; Awadallah, A.G.; Brown, E.; Hamed, K. Harold Edwin Hurst: The Nile and Egypt, past and future. Hydrol. Sci. 2016, 61, 1557-1570. [CrossRef]

81. Koutsoyiannis, D. Scale of water resources development and sustainability: Small is beautiful, large is great. Hydrol. Sci. J. 2011, 56, 553-575. [CrossRef]

82. Pettoa, A.; Merkohasanajb, M.; Lushajc, A.; Bogdani-Ndinid, M.; Lushaje, A.; Lushajf, B.M.; Eneida Isufajb, S.I.; Kodrab, E.; Sopajb, E.; Demiraj-Bruçig, E.; et al. The Expected Impacts of Climate Changes to the Transboundary Water Resources in Vjosa River Catchment, Albania. Online Int. Interdiscip. Res. J. 2014, 2050, 96-103. 